\title{
Technical Aspects of Invaginacionnoj Appendectomy
}

\author{
Shaposhnikov Veniamin Ivanovich* \\ Professor of Surgical Diseases, Noncommercial Educational Private Institution of Higher Education, Russia
}

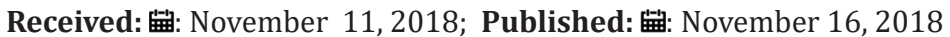

*Corresponding author: Shaposhnikov Veniamin Ivanovich, Professor of Surgical Diseases, Noncommercial Educational Private Institution of Higher Education, Russia

Keywords: Vermiform Process; Stump; Invaginacionnoe Dive

\section{Introduction}

In the $10^{\text {th }}$ century were developed the basic principles of surgical treatment of acute appendicitis. Much of the credit for this matter belongs Koheru, Mar-Burneju, Volkovichu, Djakonovu and other surgeons. Were developed by the operational access to the tree, techniques appendectomy and drainage of the abdominal cavity. Special attention was given to the technique of peritonizacii the stump of this body. Their ways suggested Fowler, Lexer, Rostovtsev, rusanov and other surgeons [1]. All authors in his writings reflect the importance of the peritonizacii stump vermiform process by dipping it into the lumen of the cecum through overlay kisetnogo and Z-shaped seams [1-3]. However, it does not dive into the lumen of the gut and immurement stump in a Pocket formed by the serous shell. This sometimes led to the formation of abscesses and faecal fistulae in the right iliac region, because submerged fragments of inflamed tissue. Virtually every appendectomy ended development of an immured in a zone mikroabscessa stump, which is then opened with enough clearance in the cecum. For this reason, the development of a method that would provide true dive Appendix stump clearance in the cecum, deserves attention.

\section{Materials and Methods}

Among 105 patients with acute appendicitis, of whom 58 (55.3\%) It was kataralno and 47 (44.7\%) flegmonoznoe inflammation, after implementation of the appendectomy Stump Sprouts was submerged in the lumen of the cecum as follows [46]. After bandag-ing and clipping bryzhejki vermiform process is pulled up. At a distance of $1.0-1.5 \mathrm{~cm}$ from the top of the resulting Cone (the base of the vermiform process) are superimposed two serous polukisetnyh seam (from the inside of the outer side of it), that perform another role derzhalok. Based on the process of the serosa circularly nadsekaetsja and vyvorachivajas inside out mucous to exfoliate from the polukisetnyh line of stitches.

Following this process stretches and naked the mucous membrane of the cecum is superimposed a thin nylon or rayon circular ligature. (Figure 1) provides an illustration of the execution phase of the operation, where 1 is a vermiform process, 2-3, the cecum is the serosa, 4-5, mucosa-Ligature on the mucous membrane, 6 strand polukisetnogo (Figure 2). Not reducing the tension of the tissue above the ligature superimposed clip and beneath it is dissected linking plot of the mucous membrane of the founding of the vermiform process. As soon as it happened, stretched mucosa cecum along with the node is shifting toward its clearance. Inverted inside out the edges of the serous shell shifted inwards, polukisetnye joints are tightened, resulting in peritonizacii of injured tissues.

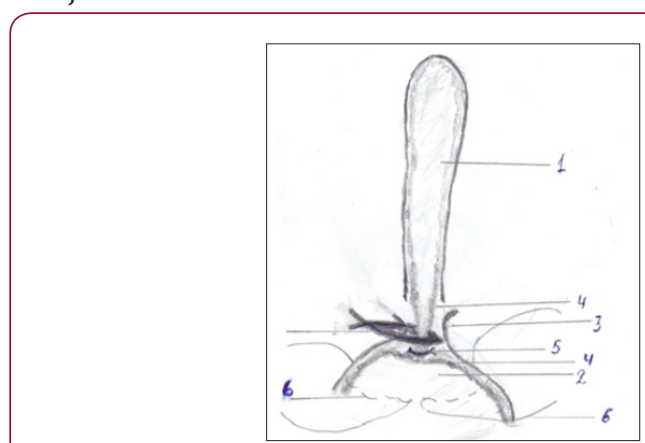

Figure 1: Rayon Circular Ligature.

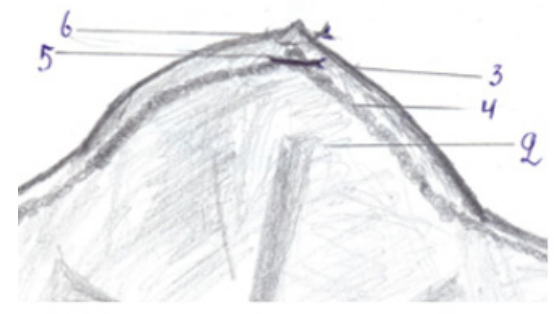

Figure 2: Shows the completed phase of the operation, where 2 is the cecum, $3 \& 4$-serosa Mucosa, 5-Ligature on the mucous membrane, 6-tied polukisetnye seams. 


\section{Resultants and Discussion}

All 105 patients complications during and in the immediate postopera-tive period was not observed. Surgical technique easily doable. Comes true invaginacija mucous membranes of the transition zone between the base process and blind gut, the lumen of the intestine. The risk of mikroabscessov in invaginirovannyh area of tissue decreases. It creates the conditions for the exclusion of traumatized tissue in the lumen of the gut, which is important in the prevention of postoperative purulent complications.

\section{Conclusion}

The proposed methodology is somewhat different from appendectomy existing. It helps reduce the risk of development of purulent complications in the field performed appendecto-my. It can be used during laparoscopic appendectomy.

\section{Annotation}

The author describes the technique of dive invaginacionnogo stump vermiform process clearance in the cecum. The method was applied at 105 patients suffering acute appendicitis of whom

\section{ISSN: 2574-1241}

DOI: 10.26717/BJSTR.2018.11.002055

Shaposhnikov Veniamin Ivanovich. Biomed J Sci \& Tech Res

(c) (i) This work is licensed under Creative

Submission Link: https://biomedres.us/submit-manuscript.php
58 (55.3\%) It was kataralnoe and 47 (44.7\%) flegmonoznoe inflammations. Complications were observed.

\section{The Purpose of Isslevovanijaj}

Describe the technique of dive invaginacionnogo stump vermiform process clearance in the cecum.

\section{References}

1. Borisov AE, Levin LA (2002) Laparoscopic appendectomy. Video endoscopic intervention on the organs of the abdomen, chest and retroperitoneal space. Guide for physicians St Petersburg p. 62-75.

2. Kolesov VI (1972) Clinic and treatment of acute appendicitis. Leningrad: Medicine Petrovsky Bv Surgical p. 344.

3. Petrovsky BV (1980) Surgical diseases. M Medicine p. 584.

4. Savchuk BD (1988) Vermiform process./clinical surgery. Reference guide for doctors under the edi-torship of Ym Pancyreva. Moscow medicine pp. 262-267.

5. Skripnichenkod F (1986) Emergency abdominal surgery. Kiev health p. 350.

6. Matjashin IM (1979) Gluzman AM Handbook of surgical operations. Kiev Health.

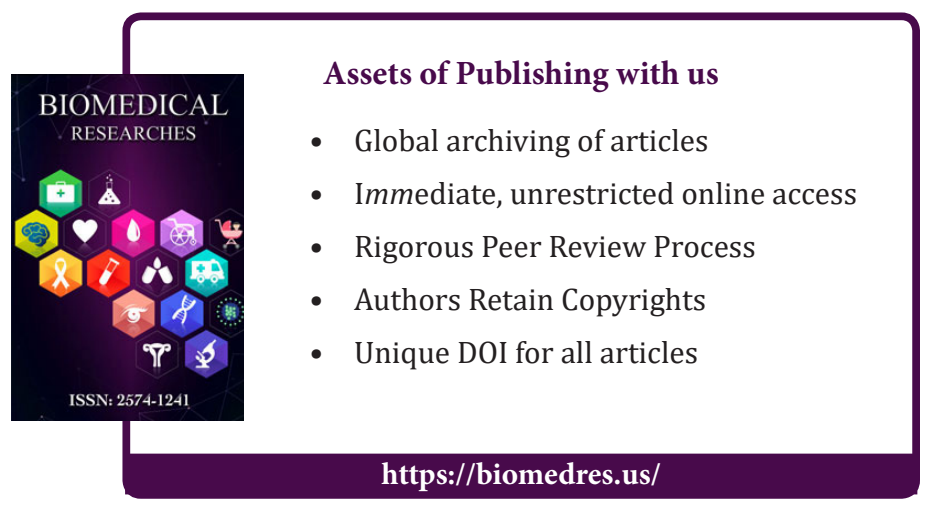

